H $\quad$ H $\quad$ H $\quad$ H

THE GIRL FROM GOD'S COUNTRY:

NELL SHIPMAN AND THE SILENT CINEMA

Kay Armatage

In The Girl from God's Country, Kay Armatage reintroduces film studies scholars to Nell Shipman, a pioneer in both Canadian and American film, and one of proportionately numerous women from Hollywood's silent era who wrote, directed, produced, and acted in motion pictures. Born and raised in British Columbia, Shipman became a contract actress for Vitagraph Studios, starring in God's Country and the Woman (1915) and Back to God's Country (1919), among other films. These action-packed adventure melodramas, in which the heroine is called upon to rescue her husband and defeat the villain, were immensely successful. Later, Shipman started up her own production company to make films centred on her screen persona, 'the girl from God's country.' By the mid-1920s, however, the formation of the large Hollywood studios and vertical integration closed down the independents, Shipman among them. Nevertheless, she continued writing until her death in 1970.

Through the use of social history, feminist film theory, and biography, Armatage creates a portrait of a woman film pioneer. Using Shipman's working life as a window to the profession, Armatage explores the position of women in modernism, the developing film industry, and cinematic practice of the 1920s. The Girl from God's Country also contextualizes Shipman's work within the development of Hollywood as a locus of artistic production as well as in relation to women filmmakers from Europe, Australia, Russia, and the United States. This book brings Shipman back to life.

KAY ARMATAGE is an associate professor in Cinema Studies and Women's Studies at the University of Toronto. She is co-editor of Gendering the Nation: Canadian Women's Cinema (1999). 
This page intentionally left blank 
H $\quad$ H $\mathbf{H}$ H

\section{The Girl from God's Country: Nell Shipman and the Silent Cinema}

Kay Armatage

UNIVERSITY OF TORONTO PRESS

Toronto Buffalo London 


\section{- $\bar{w} \bar{w}$ w.utppublishing.com}

(C) University of Toronto Press Incorporated 2003

Toronto Buffalo London

Printed in Canada

ISBN 0-8020-4414-X (cloth)

ISBN 0-8020-8542-3 (paper)

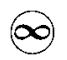

Printed on acid-free paper

\section{National Library of Canada Cataloguing in Publication}

\section{Armatage, Kay}

The girl from God's country : Nell Shipman and the silent cinema /

Kay Armatage.

Includes bibliographical references and index.

ISBN 0-8020-4414-X (bound) ISBN 0-8020-8542-3 (pbk.)

1. Shipman, Nell, 1892-1970 - Criticism and interpretation. I. Title.

PN1998.3.S55A7 $2003 \quad 791.43^{\prime}{ }^{\prime} 023^{\prime} 092 \quad$ C2002-905658-6

University of Toronto Press acknowledges the financial assistance to its publishing program of the Canada Council for the Arts and the Ontario Arts Council.

This book has been published with the help of a grant from the Humanities and Social Sciences Federation of Canada, using funds provided by the Social Sciences and Humanities Research Council of Canada.

University of Toronto Press acknowledges the financial support for its publishing activities of the Government of Canada through the Book Publishing Industry Development Program (BPIDP). 